\title{
The Julianna pegmatite vein system at the Piława Górna Mine, Góry Sowie Block, SW Poland - preliminary data on geology and descriptive mineralogy
}

\author{
Adam SZUSZKIEWICZ1, *, Eligiusz SZEŁĘG ${ }^{2}$, Adam PIECZKA ${ }^{3}$, Sławomir ILNICKI ${ }^{4}$, \\ Krzysztof NEJBERT ${ }^{4}$, Krzysztof TURNIAK $^{1}$, Magdalena BANACH ${ }^{5}$, Marek ŁODZIŃSKI ${ }^{6}$, \\ Roman RÓŻNIAK ${ }^{5}$ and Piotr MICHAŁOWSKI ${ }^{5}$ \\ 1 Institute of Geological Sciences, University of Wrocław, M. Borna 9, 50-204 Wrocław, Poland \\ 2 Department of Geochemistry, Mineralogy and Petrology, Faculty of Earth Sciences, University of Silesia, Będzińska 60, \\ 41-200 Sosnowiec, Poland \\ 3 Department of Mineralogy, Petrography and Geochemistry, AGH University of Science and Technology, Al. Mickiewicza \\ 30, 30-059 Kraków, Poland \\ 4 Institute of Geochemistry, Mineralogy and Petrology, University of Warsaw, Żwirki i Wigury 93, 02-089 Warszawa, Poland \\ 5 DSS Company, Piława Górna Mine, Sienkiewicza 96, 58-240 Piława Górna, Poland \\ 6 Department of General Geology and Geotourism, AGH University of Science and Technology, Al. Mickiewicza 30, 30-059 \\ Kraków, Poland
}

Szuszkiewicz A., Szełęg E., Pieczka A., Ilnicki S., Nejbert K., Turniak K., Banach M., Łodziński M, Różniak R. and Michałowski P. (2013) The Julianna pegmatite vein system at the Piława Górna Mine, Góry Sowie Block, SW Poland - preliminary data on geology and descriptive mineralogy. Geological Quarterly, 57 (3): 467-484, doi: 10.7306/gq.1097

\begin{abstract}
The newly discovered Julianna pegmatitic system from the Piława Górna Quarry (the Góry Sowie Block, Sudetes, NE margin of the Bohemian Massif) is described in terms of geological setting, petrography and descriptive mineralogy. The system represents the largest pegmatitic occurrence in the Polish Sudetes and consists of a complex network of cogenetic rare-element granitic pegmatites that intruded into tectonized amphibolite as discordant dikes. The pegmatites range from barren and weakly zoned to texturally well-differentiated ones that are composed of a fine-grained border zone, coarse-grained wall zone, graphic and blocky feldspar intermediate zones and a quartz core. Unidirectional and skeletal solidification textures are well-developed. The Julianna pegmatites consist of rock-forming plagioclase $\left(\leq A n_{39}\right)$, microcline, quartz and biotite accompanied mostly by accessory to minor muscovite, tourmaline, garnet and beryl. They crystallised from anatectic melt of hybrid NYF (niobium-yttrium-fluorine) + LCT (lithium-cesium-tantalum) geochemical characteristics. Pegmatites with a low to moderate degree of fractionation, that dominate in the Julianna system, bear NYF-signature accessory minerals, such as allanite-(Ce), columbite-, euxenite- and samarskite-group minerals, fergusonite-(Y) and gadolinite-(Y). However, rare dikes that attained a very high degree of fractionation contain typical minerals of LCT-signature including tourmalines of the elbaite-olenite-rossmanite series, lepidolite, lithiophilite, spodumene, Cs-rich beryl and pollucite.
\end{abstract}

Key words: rare-element pegmatite, mixed (NYF + LCT) signature, granitic pegmatites, Piława Górna, Góry Sowie Block, Sudetes.

\section{INTRODUCTION}

Until the beginning of the 1900s, pegmatites of the Góry Sowie Block (GSB) were locally mined for feldspar and quartz for use in the ceramics and glass industry. The mining activity included underground exploitation and was especially intensive in the area between Piława, Różana, Owiesno and Bielawa (Meister, 1932 fide Lis and Sylwestrzak, 1986). Since the end of

* Corresponding author, e-mail: adam.szuszkiewicz@ing.uni.wroc.pl

Received: December 14, 2012; accepted: April 16, 2013; first published online: May 13, 2013 the exploitation, no new large-scale occurrences have been uncovered. Thus, contemporary studies of GSB pegmatites have been limited to old quarries, mine dumps, and small natural exposures along the shoreline of Lake Bystrzyckie and road and railroad cuts. As a consequence, the amount of available research material was insufficient for studying rare minerals and the lack of in situ exposures of larger pegmatitic bodies precluded systematic research on their textural and geochemical internal zoning.

In 2001 the Dolnośląskie Surowce Skalne mining company initiated a project to open a quarry for amphibolite and migmatite at Piława Górna. At the end of 2007, the preparatory work uncovered the first portion of a system of pegmatitic veins, which was later named "Julianna" (Szełęg et al., 2010). Various sections of Julianna were exposed between 2008 and 2010. The whole peg- 
matitic system consisted of numerous anastomosing and locally cross-cutting veins hosted by tectonized amphibolites. In 2009, when the most complete exposure was achieved, the system extended over 60-80 metres in plan view and was defined by three main dikes oriented NNE-SSW and dipping WNW at moderate-to-steep angles. Some pegmatitic dikes could be traced for up to 50 metres in vertical section. The dimensions of this exposure, unprecedented on the scale of the whole GSB massif, and the possibility of sampling various sections of the veins systematically uncovered during the ongoing exploitation offered a unique opportunity for comprehensive petrological and mineralogical studies.

This paper aims at providing the first coherent report on the results of field studies of the Julianna system, supported by identification of selected minerals by means of X-ray powder diffraction, semi-quantitative SEM-EDS or quantitative WDS electron microprobe analyses. The present study focused on the low- to moderately-evolved pegmatites which largely dominate in the Julianna system. However, sections of pegmatites that display a very high degree of geochemical fractionation, as shown by the presence of Cs- and Li-rich minerals, were also found (Pieczka et al., 2010c).

\section{GEOLOGICAL SETTING}

The Sudetes form the NE margin of the Bohemian Massif and represent the NE termination of the European Variscan orogenic belt. The region extends between the WNW-ESE trending regional tectonic zones of the Upper Elbe and the Middle Odra. Sudetic rocks subcrop under Permo-Mesozoic and Miocene strata in the NE and SE, respectively, and merge with the Neoproterozoic Lusatian Massif towards the NW (Mazur et al., 2007 and references therein). The Sudetes are generally built of: (1) basement units that include fragments of Cadomian crust with Lower Paleozoic metasedimentary and metaigneous rocks, injected by Variscan granitoids and (2) a late- to post-Variscan cover of Lower Carboniferous-Cenozoic age. Based on major differences in lithology, structural characteristics and geological evolution, the Sudetes are divided into western, central and eastern parts, each consisting of a number of smaller, mostly tectonically bounded, units (Mazur et al., 2007). Thus the whole region represents a complex mosaic of distinct tectono-stratigraphic units, whose mutual relations are blurred by block tectonics related to the Alpine orogeny. The Sudetic Boundary Fault, a NE-SW trending Late Variscan structure rejuvenated during the Alpine orogeny (Aleksandrowski et al., 1997; Badura et al., 2003), separates the Sudetes into a topographically distinctive mountainous part in the SW and strongly peneplained lowlands of the Fore-Sudetic Block in the NE, now mostly under thick Cenozoic cover.

The triangular Góry Sowie Block (GSB) is one of the main geological units of the Central Sudetes (Fig. 1). It extends over $\sim 600 \mathrm{~km}^{2}$ between Szczawno Zdrój, Srebrna Góra and Oleszna, SW of Wrockaw (SW Poland). The GSB is crossed by the Sudetic Boundary Fault and about two-thirds of the area is located in the Fore-Sudetic Block, whilst the remaining one-third is in the elevated mountainous part of the Góry Sowie Mts. The foreland domain is considered to represent an intersection level about $5 \mathrm{~km}$ deeper than the mountainous part (Żelaźniewicz, 1995).

The GSB (Fig. 1) is composed predominantly of metasedimentary and felsic metaigneous gneisses and migmatites, with minor intercalations of amphibolite, granulite, recently discovered eclogite (Ilnicki et al., 2010, 2011), hyperite, highly serpentinised mantle rocks, marble and calc-silicate rocks (e.g., Polański, 1955; Grocholski, 1967; Morawski, 1973; Kryza, 1981; Żelaźniewicz, 1985, 1987; Gunia 1997). The metamorphic suite is cut by granites, aplites, pegmatites, rhyolitic and lamprophyric dikes as well as by barite and quartz hydrothermal veins. The late Proterozoic-Early Cambrian protolith (Gunia, 1985; Kröner and Hegner, 1998; Kryza and Fanning, 2007) has undergone polymetamorphic evolution (Kryza, 1981; Żelaźniewicz, 1987, 1990). An early high-pressure/high-temperature (HP-HT) episode at $\sim 400$ Ma was overprinted by a high amphibolite facies event at ca. 385-370 Ma (Breemen et al., 1988; Brueckner et al., 1996; O’Brien et al., 1997; Bröcker et al., 1998; Aftalion and Bowes, 2002; Gordon et al., 2005; Kryza and Fanning, 2007). Decompression led to local partial melting and formation of anatectic granodiorites and pegmatites (Kryza, 1981; Timmermann et al., 2000).

Piława Górna is located in the east of the GSB foreland, about $10 \mathrm{~km}$ SE of Dzierżoniów and over $50 \mathrm{~km} \mathrm{SW}$ of Wrocław (Lower Silesia, SW Poland). The "Piława Górna" open quarry, situated on Rybak Hill $1.5 \mathrm{~km}$ north of the town (Fig. 2), exploits the migmatite-amphibolite rock deposit with over 323 million tons of estimated resources. Migmatite accounts for about $72 \%$ of the raw rock and the rest is mainly amphibolite, with minor bodies of granitic pegmatite. Rock processing takes place in a plant located nearby (Fig. 3). The final products are used as construction and concrete rock aggregates.

\section{THE GÓRY SOWIE PEGMATITES}

In the GSB, pegmatites occur as pods, lenses and dikes in amphibolites, migmatites, gneisses and granulites, rarely in other rock types (Smulikowski, 1952; Polański, 1955; Grocholski, 1964, 1967; Kryza, 1977; Żelaźniewicz, 1987). At most occurrences the pegmatites are from centimetres to $1 \mathrm{~m}$ thick, reaching several metres only exceptionally. Textural and mineral zonation is well-pronounced only in the thickest pegmatitic bodies. Field relationships allow the distinction of an older generation of pegmatites, concordant with the host rocks, mainly migmatites, and a younger generation crosscutting the surrounding rocks discordantly. Syntectonic older pegmatites are clearly related to the Late Devonian migmatitisation event. According to Żelaźniewicz (1990), sub-vertical pegmatitic veins of the younger generation were emplaced along generally $\mathrm{N}$-trending extensional fractures in the $\mathrm{D}_{4}$ tectonometamorphic event. Crystallisation ages of the GSB pegmatites were established at $370 \pm 4$ Ma using muscovite from Lutomia (Breemen et al., 1988; Rb-Sr method) and 383-370 Ma using xenotime from Zagórze Ślaskie (Timmermann et al., 2000; U-Pb method).

Pegmatites of the GSB have been well-known for large, well-developed crystals of K-feldspar, beryl, garnet and tourmaline since at least the early 1800s (Sachanbiński, 1972, 1973; Lis and Sylwestrzak, 1986 and references therein). The most spectacular specimens were encountered during mining of the pegmatitic bodies near Piława Górna, Kamionki, Bielawa, Różana, Owiesno and Grodziszcze in the Fore-Sudetic Block. Most of the pegmatitic bodies have a simple mineral composition, limited to rock-forming quartz, albite-oligoclase, K-feldspar and micas. Common accessory minerals include tourmaline, garnet and apatite and locally also beryl whilst hornblende, andalusite, sillimanite, kyanite, cordierite, zircon, titanite and others are rare (Sachanbiński, 1972; Kryza, 1977). Hybridization of pegmatitic melt emplaced in metabasites resulted in enrichment in biotite, epidote, hornblende, apatite and tourmaline at the expense of quartz, plagioclase and muscovite and sometimes led to the formation of cordierite-bearing bodies (Kryza, 


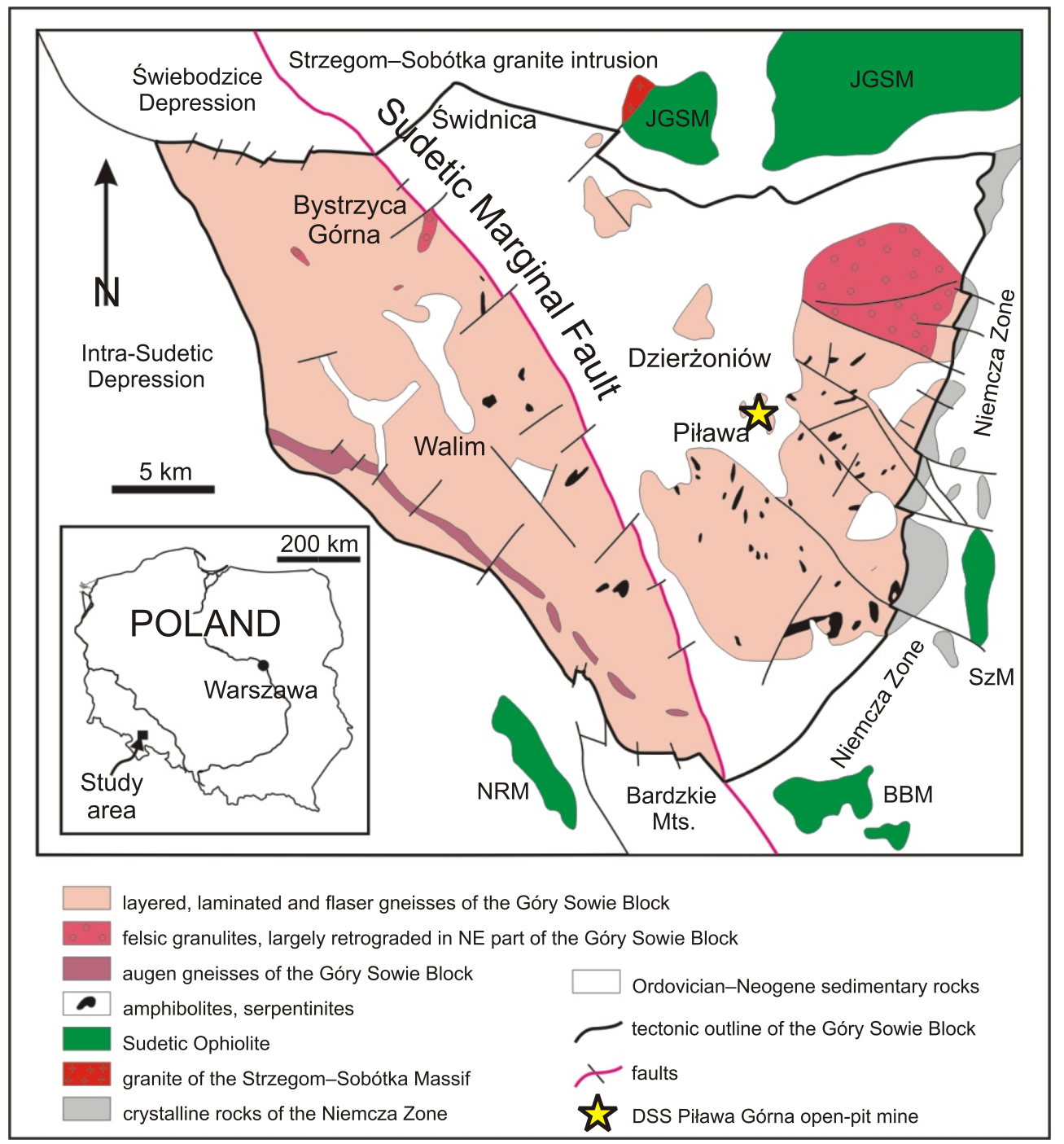

Fig. 1. Geological map of the Góry Sowie Block (after Bröcker et al., 1998; modified)

BBM - Braszowice-Brzeźnica Massif, JGSM - Jordanów-Gogołów Serpentinite Massif; NRM - Nowa Ruda Massif, SzM - Szklary Massif (all constitute the Sudetic Ophiolite)

1977). The garnet belongs to the almandine-spessartine series and the tourmaline is mostly Al- and Mg-enriched schorl grading towards Li-enriched schorl and Fe-bearing elbaite only locally (Pieczka, 1996; Pieczka et al., 1997, 2004). Beryl commonly displays low contents of alkali elements, mainly $\mathrm{Na}$ (Sachanbiński, 1973; Łodziński, 2007). Nb-Ta oxides, up to 0.5 $\mathrm{cm}$ in size, have occasionally been found near Piława Górna (Pilati, 1863 fide Traube, 1888; Römer, 1864; Roth, 1867) and in the area of Owiesno-Kietlice (Łodziński, 2008; Łodziński and Pieczka, 2008). Locally the enrichment in $\mathrm{P}$ of pegmatitic melt resulted in the crystallisation of phosphates, such as sarcopside (with the type locality at Michałkowa), huréaulite, vivianite, triplite, ferrisicklerite, graftonite, Ca-rich beusite, staněkite and alluaudite described from Michałkowa, Lutomia and Piława Górna (Sadebeck, 1855 fide Fiedler, 1863; Websky, 1868; Dathe and Finckh, 1924; Hintze, 1933; Pieczka et al., 2003).

Geochemical studies of the GSB crystalline rocks (Sachanbiński, 1971; Mikuszewski et al., 1976) have not re- vealed significant concentrations of $\mathrm{Li}, \mathrm{Be}, \mathrm{Nb}$ and REEs although Sachanbiński (1971) noted slightly elevated concentrations of Be in some of the gneisses. Mikuszewski et al. (1976) concluded that the metamorphic conditions were not high enough to generate zoned pegmatites with elevated concentrations of incompatible elements.

Available data on the concentrations of trace elements in some minerals such as micas (Zawidzki, 1971; DumańskaSłowik, 2004), garnet (Pieczka et al., 1997), beryl (Łodziński, 2007) and tourmaline (Pieczka, 1996; Pieczka et al., 2010b), indicate a relatively primitive geochemical character of the majority of the GSB pegmatites. However, fragments of pegmatites with signs of advanced geochemical fractionation and significant Li-enrichment have also been observed (Pieczka et al., 2003, 2004, 2010c, 2012; Nejbert et al., 2010). This suggests that, at least locally, the pegmatitic melts attained high concentrations of rare elements. 




Fig. 2. Geological map of the Piława Górna Mine area (after Cymerman and Walczak-Augustyniak, 1988; Szełęg and Gałuskina, 2010; modified)

\section{PETROGRAPHY OF THE JULIANNA PEGMATITE AND OF THE HOST ROCKS}

Migmatites and amphibolites exposed in the Piława Górna Quarry show generally gradational contacts. The migmatites are composed of quartz, K-feldspar, biotite, subordinate muscovite, garnet and accessory zircon, apatite and sillimanite. Layer-, fold- and net-structured migmatite varieties are observed. Ophthalmitic augen-like textures are also present and indicate post-anatectic porphyroblastic growth of K-feldspars. Leucosome segregations cutting the host rock as discordant veinlets are not uncommon and in places may be considered as synmigmatitic granite and pegmatite. The amphibolites are composed of amphibole and plagioclase with minor garnet and locally abundant biotite. IImenite, rutile, clinozoisite and quartz are accessory minerals. Some of these also contain relicts of clinopyroxene and spinel. Due to strong but heterogeneous deformation and metamorphism they show a large textural diversity from massive to well-foliated varieties. The foliation strongly varies due to folding and generally dips at 220/70. Massive amphibolites that occur in weakly strained domains contain abundant relics of eclogitic textures. These relics are variably obliterated by retrogression under amphibolite facies conditions and are not observed in the foliated amphibolites. In places, relict domains of retrogressed but not amphibolitised eclogites have been found (Ilnicki et al., 2010), providing evidence of the first in situ occurrence of eclogites in the GSB. These rocks document $\mathrm{HP}$ metamorphism at temperatures of $730-840^{\circ} \mathrm{C}$ and pressures of 25-26 kbar prior to nearly isothermal decompression to pressures <5-6 kbar (Ilnicki et al., 2011, 2012). Both the migmatites and amphibolites are fractured; however, due to the difference in their rheological properties the fracturing is developed to a greater extent in the amphibolites. Dominant tectonic fractures observed in the quarry trend SW-NE and NW-SE.

During quarrying between the end of 2007 and the middle of 2010 various sections of the Julianna pegmatitic system were exposed in the SW part of the quarry (Figs. 3 and 4). Pegmatites occurred as numerous anastomosing, locally cross-cutting veins that intruded along a tectonic zone segmenting the amphibolite (Szełęg et al., 2010). The overall geometry of the system was strongly controlled by rheological

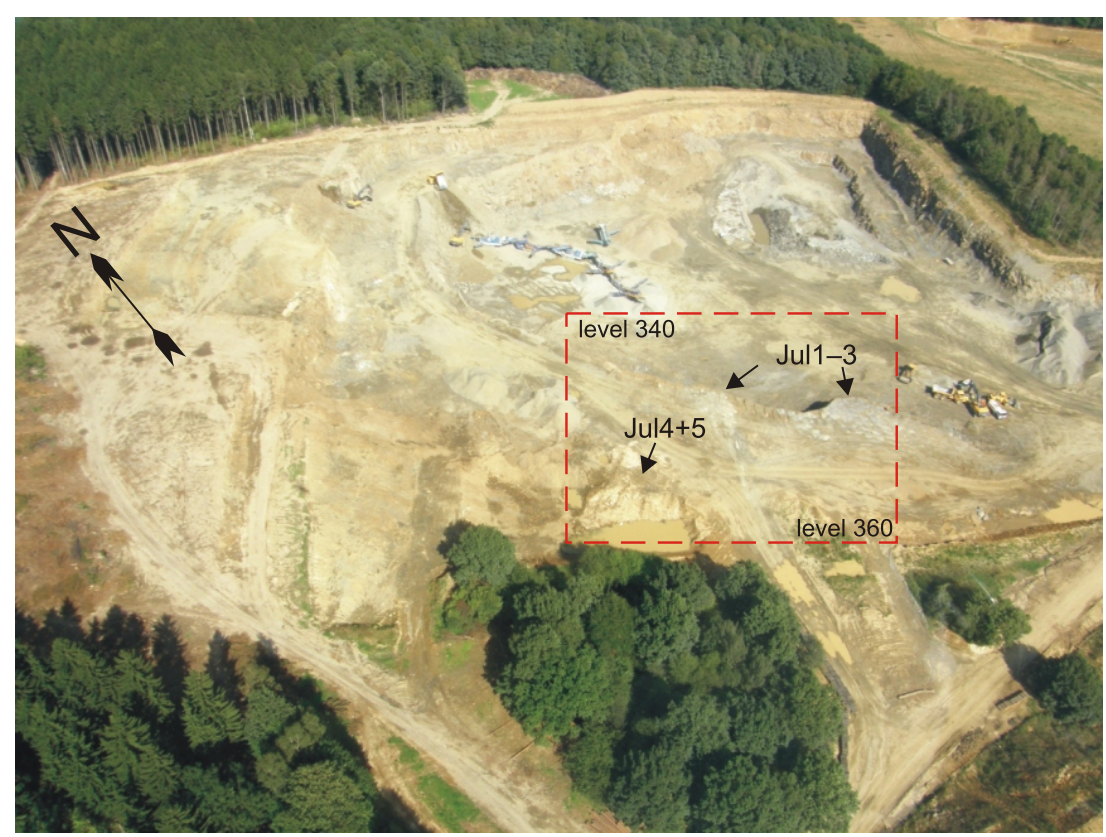

Fig. 3. The Piława Górna Mine in September 2008 



Fig. 4. The Julianna pegmatitic system

A - schematic horizontal and vertical cross-sections; quartz cores that were identified in veins Jul2, Jul3 and Jul4 are marked; B - in an about $18 \mathrm{~m}$ long horizontal cross-section veins Jul4 and Jul5 with a short apophysis between in a horizontal cross-section on the 360 a.s.I. level; C - view of the Jul1-3 veins from the 340 a.s.l. level along the $50 \mathrm{~m}$ long fragment of the quarry's wall

properties of the country rocks. Large angular blocks of amphibolite were enveloped by pegmatite while smaller ones were also incorporated into the thicker pegmatitic veins. The amphibolite xenoliths were in places rotated with foliation oriented at an angle with respect to the foliation of the amphibolite surrounding the pegmatites. Generally they retained an angular shape and were boudinaged or streaked out only exceptionally. Individual pegmatitic bodies became thickest in pressure shadows between large amphibolite blocks.

In 2009 the whole system extended over 60-80 metres in plan view (Fig. 4). Some of the pegmatitic dikes could be traced up to $50 \mathrm{~m}$ in vertical section between levels 320 and 360 a.s.I. They formed a complex system with a well-defined framework that consisted of three main dikes striking NNE and dipping 30 to $80^{\circ}$ WNW (marked as Jul1, Jul2 and Jul $4+5$ in Fig. 4). They were accompanied by over 20 smaller subordinate veins and apophyses that were randomly arranged and often terminated abruptly. The average thicknesses of Jul1, Jul2 and Jul4+5 were about $0.5,1.5$ and $4 \mathrm{~m}$, respectively. Vein Jul $4+5$ split in its upper section into two similar-sized bodies of Jul4 and Jul5. The pegmatites were essentially undeformed and showed no features of sequential emplacement in places where they cross-cut one another. Amphibolite, typically weakly foliated, often showed strong schistosity when approaching the pegmatite contacts. The schistosity was parallel to the contact and its orientation varied due to the irregular course of most of the pegmatitic bodies. In general the pegmatites had sharp contacts with the host rock. Thin pegmatitic veinlets rarely penetrated along the amphibolite schistosity. Thicker pegmatitic bodies developed a discontinuous biotite envelope up to a few centimetres thick. No other exocontact features were observed.

Based on the extent of textural and geochemical differentiation, the pegmatites could be tentatively grouped into: (1) primitive quartz-feldspars-biotite pegmatites with accessory garnet, essentially homogeneous with locally developed graphic texture (e.g., Jul1); (2) more evolved garnet-, tourmaline- and in places also muscovite-bearing pegmatites that posses texturally and mineralogically differentiated segments as well as homogeneous portions (e.g., Jul2 and Jul3) and (3) the most complex zoned pegmatites with the richest mineral assemblage (Table 1), in which primary muscovite succeeds biotite in the central zones (e.g., Jul4 and Jul5). The degree of textural differentiation essentially correlates with the pegmatite's dimensions. Usually the thickness of the most primitive bodies does not exceed $30 \mathrm{~cm}$.

The idealized zone sequence (Fig. 5) begins with a discontinuous granular border zone up to a few centimetres thick. It comprises fine- to medium-grained $(<5 \mathrm{~mm})$ plagioclase of polygonal shape, plates of biotite and mostly interstitial quartz (Fig. 6). Subordinate K-feldspar occurs sporadically. The border zone is succeeded by a wall zone, where crystals are coarser by an order of magnitude than in the border zone and show preferred orientation and arrangement resulting from unidirectional growth (Fig. 6). Elongate, lath-shaped biotite crystals tend to be arranged either parallel or perpendicular to the pegmatite-amphibolite contact. The parallel arrangement is observed only locally in the outermost portion of the wall zone, whilst the perpendicular type becomes dominant inwards. Wedge-shaped feldspar crystals are oriented perpendicular to the contact with the vertex pointing to the wall. The thickness of both the border and wall zones reaches $40 \mathrm{~cm}$. Two intermediate zones can be distinguished. The outer one is composed of both potassic feldspar-quartz and plagioclase-quartz graphic intergrowths. It also contains characteristic giant biotite laths, usually flaring towards the central parts of the dikes. The amount of biotite decreases inwards, giving way to garnet and tourmaline locally accompanied by muscovite and beryl. The transition to the inner intermediate zone is marked by the disap- 
Table 1

Minerals of the low- to moderately-fractionated pegmatites of the Julianna system from Piława Górna

\begin{tabular}{|c|c|c|c|c|c|}
\hline \multirow{2}{*}{ Mineral name } & \multirow{2}{*}{$\begin{array}{l}\text { Fine-grained } \\
\text { border zone }\end{array}$} & \multirow{2}{*}{$\begin{array}{l}\text { Coarse-grained } \\
\text { wall zone }\end{array}$} & \multicolumn{2}{|c|}{ Intermediate zones } & \multirow{2}{*}{ Quartz core } \\
\hline & & & graphic zone & $\begin{array}{c}\text { blocky } \\
\text { microcline }\end{array}$ & \\
\hline Albite & + & + & + & + & \\
\hline Allanite-(Ce) & & & + & + & \\
\hline Almandine & + & + & + & + & + \\
\hline Arsenopyrite & & & & + & \\
\hline Barite & & & + & + & \\
\hline Bavenite & & & + & + & \\
\hline Beryl & & & + & + & + \\
\hline Betafite group & & & + & + & \\
\hline Biotite & + & + & + & + & + \\
\hline Bismite & & & & + & \\
\hline Bismuth native & & & & + & \\
\hline Bismuthinite & & & & + & \\
\hline Bismutite & & & + & + & + \\
\hline Calciosamarskite & & & + & + & \\
\hline Cassiterite & & & & + & \\
\hline Chalcopyrite & & & + & + & \\
\hline Cheralite & & & + & + & + \\
\hline Clinochlore & + & + & + & + & + \\
\hline Columbite-(Fe) & & & + & + & + \\
\hline Columbite-(Mn) & & & + & + & + \\
\hline Dravite & + & + & + & & \\
\hline Epidote & & & + & + & \\
\hline Euxenite-(Y) & & & + & + & \\
\hline Ferriallanite-(Ce) & & & + & + & \\
\hline Ferrowodginite & & & & + & \\
\hline Fluorapatite & & & & + & \\
\hline Fergusonite-(Y) & & & + & + & \\
\hline Fersmite & & & + & + & \\
\hline Gadolinite-(Y) & & & + & + & \\
\hline Galena & & & + & + & \\
\hline Goethite & + & + & + & + & + \\
\hline Hematite & & & + & + & \\
\hline Hingganite-(Ce) & & & & + & \\
\hline Hingganite-(Y) & & & & + & \\
\hline Hyalophane & + & + & & & \\
\hline Ikunolite & & & & + & \\
\hline Ilmenite & & & + & + & \\
\hline Ishikawaite & & & + & + & \\
\hline Ixiolite & & & + & + & \\
\hline Keiviite-(Y) & & & & + & \\
\hline Microcline & + & + & + & + & + \\
\hline Microlite group & & & + & + & \\
\hline Monazite-(Ce) & & & + & + & + \\
\hline Muscovite & & + & + & + & + \\
\hline Phenakite & & & & + & \\
\hline Plagioclase $\leq \mathrm{An}_{39}$ & + & + & + & + & \\
\hline Polycrase-(Y) & & & + & + & \\
\hline Pyrite & & & + & + & + \\
\hline Pyrochlore group & & & + & + & \\
\hline Pyrophanite & & & + & + & \\
\hline Pyrrhotite & & & + & + & \\
\hline Quartz & + & + & + & + & + \\
\hline
\end{tabular}


Tab. 1 cont.

\begin{tabular}{|c|c|c|c|c|c|}
\hline \multirow[b]{2}{*}{ Mineral name } & \multirow{2}{*}{$\begin{array}{l}\text { Fine-grained } \\
\text { border zone }\end{array}$} & \multirow{2}{*}{$\begin{array}{l}\text { Coarse-grained } \\
\text { wall zone }\end{array}$} & \multicolumn{2}{|c|}{ Intermediate zones } & \multirow[b]{2}{*}{ Quartz core } \\
\hline & & & graphic zone & $\begin{array}{l}\text { blocky } \\
\text { microcline }\end{array}$ & \\
\hline Samarskite-(Y) & & & + & + & \\
\hline Schorl & & & + & + & + \\
\hline Spessartine & & & + & + & + \\
\hline Vermiculite & + & + & + & + & + \\
\hline Vikingite $\mathrm{Ag}_{4} \mathrm{~Pb}_{8} \mathrm{Bi}_{14} \mathrm{~S}_{31}$ & & & & + & \\
\hline $\begin{array}{l}\text { Vikingite group (?) - } \\
\mathrm{Ag}_{5} \mathrm{~Pb}_{4} \mathrm{Bi}_{17} \mathrm{~S}_{32}\end{array}$ & & & & + & \\
\hline Tantalite-(Fe) & & & + & + & \\
\hline Thorite & & & + & + & \\
\hline Titanite & & & + & + & \\
\hline $\begin{array}{l}\text { Titanite group (?) }- \\
\mathrm{Ca}\left[\mathrm{Ti}_{0.33}\left(\mathrm{Al}_{0.33} \mathrm{Ta}_{0.33}\right)\right]\left[\mathrm{SiO}_{4}\right] \mathrm{O}\end{array}$ & & & & + & \\
\hline Uraninite & & & + & + & \\
\hline $\begin{array}{l}\text { Vuagnatite group (?) - } \\
\left(\mathrm{Ca}_{0.5} \mathrm{Y}_{0.5}\right) \mathrm{Al}\left[\mathrm{SiO}_{4}\right]\left(\mathrm{O}_{0.5} \mathrm{OH}_{0.5}\right)\end{array}$ & & & & + & \\
\hline Xenotime- $(\mathrm{Y})$ & & & + & + & \\
\hline Zircon & & & + & + & \\
\hline Zoisite & & & + & + & \\
\hline
\end{tabular}

The ones for which the Julianna pegmatitic system is, according to the authors' knowledge, the first Polish occurrence as well as possible new mineral species are in bold. Minerals identified only from the most evolved Li- and Cs-enriched pegmatites (see the text for details) are not included in the table due to the incomplete data on the assemblage and the position in the zoning sequence

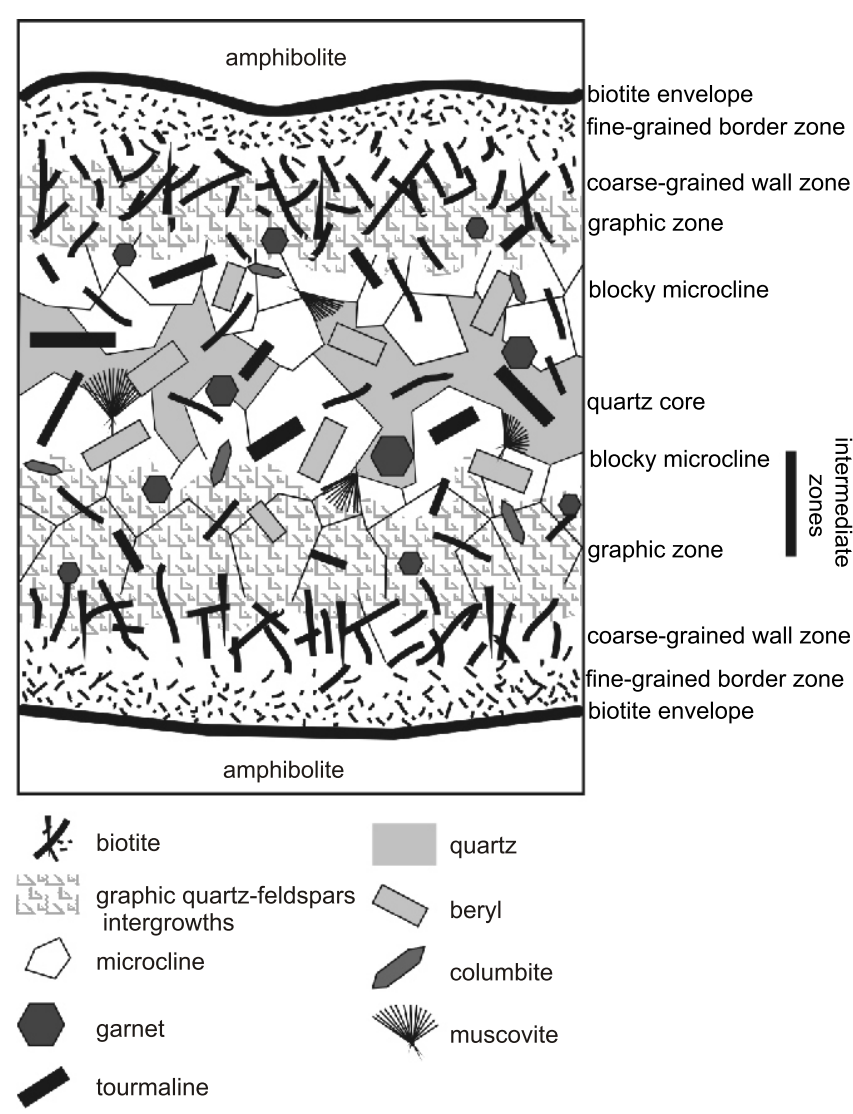

Fig. 5. Schematic cross-section of the Julianna-type pegmatite vein

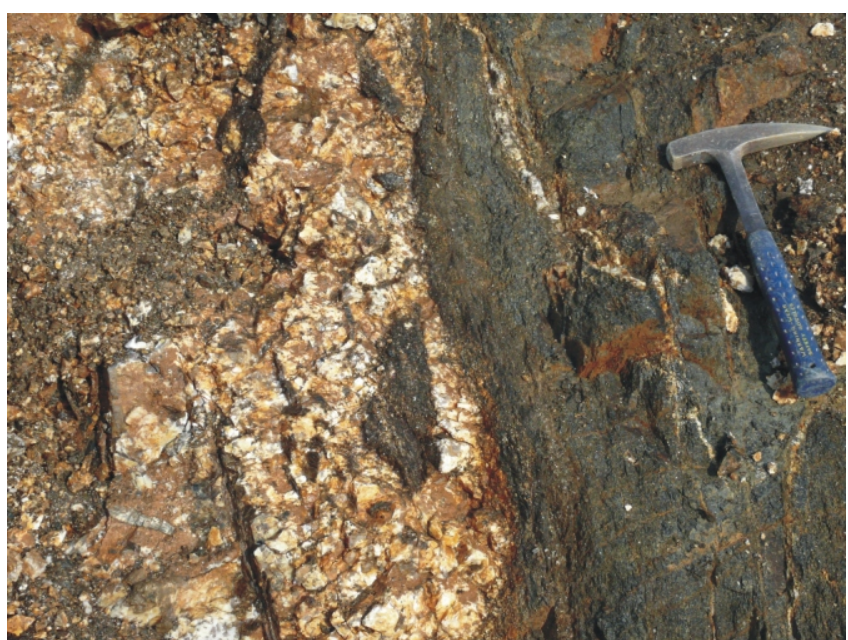

Fig. 6. The contact of the Jul4 vein with amphibolite

Transition between the outermost border zone and the wall zone is marked by larger crystal dimensions and preferred orientation with longer crystal axes more or less perpendicular to the contact plane (details in the text); a small amphibolite xenolith detached from the wall is embedded in the pegmatite; the orientation of the contact plane shown in the figure is $280 / 35$; the hammer is $27 \mathrm{~cm}$ long 
pearance of graphic texture although crystallisation of individual feldspar crystals proceeded uninterrupted across the transition border. The inner intermediate zone is essentially devoid of plagioclase and contains mainly massive (blocky) K-feldspar. Grey quartz fills interstices between feldspar crystals. The intermediate zones contain pods of symplectic intergrowths of garnet-quartz, tourmaline-quartz and muscovite-quartz. Well-developed tourmaline, garnet, beryl and columbite are the main accessory minerals. The thickness of both intermediate zones reaches up to $2 \mathrm{~m}$ although the proportions of the two units vary. Several separate quartz cores occurred roughly in the axial parts of the Jul2, Jul4 and Jul5 veins (Fig. 4). The largest one measured $1 \times 2 \times 3 \mathrm{~m}$. Smaller segregations of quartz were distributed less regularly within the intermediate zones. Massive grey quartz contains euhedral beryl, tourmaline, garnet, K-feldspar and book-like aggregates of muscovite projecting from the surrounding pegmatitic zones.

The zoning sequence described above often deviates from the idealized scheme because some units are reduced or missing in the veins. It becomes strongly asymmetrical in sub-horizontal segments of the pegmatites. In that case the thickness of the outer zones diminishes strongly in the hanging wall part and the core is displaced upwards. Besides the internal units of primary origin, the pegmatites also contain randomly distributed bodies whose nature is ambiguous, being either primary or secondary. They vary in size and are dominated by muscovite or saccharoidal, rarely platy albite (cleavelandite). Other common minerals include garnet, tourmaline and $\mathrm{Nb}$-Ta oxides. Scarce fracture fillings are limited to albite- or quartz-dominated thin $(<1 \mathrm{~cm})$ bodies found mostly in the intermediate zones. Quartz fillings are often rooted in the quartz core. They locally contain small crystals of tourmaline, garnet and muscovite as well as grains of oxide and sulphide minerals.

\section{MINERALS OF THE JULIANNA PEGMATITIC SYSTEM}

The pegmatites of the Julianna system are dominated by veins with a low to moderate degree of fractionation that consist of the rock-forming feldspars, quartz and micas accompanied by tourmaline, garnet and beryl. The assemblage of accessory minerals comprises columbite-, samarskite-, euxenite- and ilmenite-group minerals, fergusonite- $(Y)$, cassiterite, monazite-(Ce), xenotime- $(Y)$, members of the pyrochlore supergroup, gadolinite-(Y), titanite, base metal sulphides, Ag-Bi sulphosalts and others (Table 1). Rare lithium- and caesium-rich minerals, including Li-rich tourmalines and micas, spodumene and pollucite, were identified in pegmatites that attained an exceptionally high degree of fractionation (Pieczka et al., 2010c). However, they were found only in a few loose rock fragments with little indication of a broader geological context. Therefore neither a complete description of the $\mathrm{Li}$ - and Cs-bearing mineral assemblage nor its position within the pegmatitic zoning sequence can be given at present.

\section{FELDSPARS}

White to greyish white potassic feldspar constitutes most of the pegmatites' volume. It shows optical features of perthitic microcline though the presence of orthoclase in some veins cannot be ruled out. In the outermost pegmatitic zones K-feldspar often contains Ba-rich domains that are usually developed close to secondary albite replacing primary K-feldspar. The relative abundance, mode of occurrence and crystal size of
K-feldspar define the overall textural zoning of the pegmatitic bodies. Large crystals $(>40 \mathrm{~cm}$ ) with well-developed faces, encountered in the inner intermediate zone, possess cores of graphic intergrowths surrounded by quartz-free perthite (Fig. 7B, D). They generally show a stout tabular habit that evolves into elongate columns projecting from the footwall into the quartz core in the subhorizontal apophyses (Fig. 7C, D). Although feldspar is typically euhedral against quartz of the quartz core, the opposite tendency is sometimes also observed. In such cases the feldspar-quartz contact shows a surface which is corrugated in a way similar to growth surfaces in graphic K-feldspar-quartz intergrowths.

White plagioclase, abundant in the outermost parts of the pegmatites, can be the only feldspar in the border and wall zones (Fig. 7A). The wall zone often hosts wedge-shaped crystals, perpendicular to the contact. The amount of plagioclase decreases throughout the outer intermediate zone and the blocky feldspar zone is plagioclase-free near the quartz core (Fig. 7B). Plagioclase shows progressive sodium enrichment toward the vein centre from $A n_{39-12}$ in the marginal zones to $A n_{16-0}$ in the intermediate zones. Primary albite $\left(A n_{5-0}\right)$ is commonly observed as plagioclase rims and tabular inclusions in microcline. White, slightly bluish and colourless platy albite crystals $(<2 \mathrm{~cm})$ form pods distributed irregularly within the inner intermediate zone and are present in the interstices between giant crystals of K-feldspar in the largest Jul4 and Jul5 dikes.

Albitization of primary feldspars is widespread and although its extent varies throughout a single pegmatite body it is particularly intensive in the outermost pegmatitic zones. In the intermediate zones or quartz core, veinlets and streaks of secondary albite cut plagioclase and K-feldspar marking fluid migration paths. In places secondary albite forms more voluminous irregular pods locally associated with fine-grained muscovite and tourmaline. Profound albitization of K-feldspar results in creating small $(<2 \mathrm{~cm})$ voids which may be filled with clay minerals.

\section{MICAS}

Micas are black to dark brown biotite and colourless to silvery-white muscovite. In the primitive veins biotite is the only primary mica from the margin up to the quartz core. Except for the granitic border zone, it usually forms strongly elongated $(<60 \mathrm{~cm}$ ) laths (Fig. 8). Pseudohexagonal plates occur rarely. Chloritization of biotite is widespread. In more evolved pegmatites muscovite gradually succeeds biotite in the outer intermediate zone and is found up to the quartz core (Fig. 9). Short apophyses that branched from vein Jul5 towards Jul4 were exposed on the 360 a.s.I. quarry level (Fig. 7A, B), and were particularly abundant in muscovite. Individual muscovite blades rarely exceed $10 \mathrm{~cm}$. In contrast to biotite, they are distributed less regularly and form large $(<15 \mathrm{~cm})$ book- and rosette-like aggregates. Pods of chaotically arranged crystals and plumose aggregates are rare. Intermediate zones host also muscovite-quartz symplectites. Primary muscovite is commonly accompanied by garnet, tourmaline and beryl. A later generation of fine-grained muscovite covers the faces of other minerals, mainly K-feldspar, beryl and tourmaline or is present in fracture fillings and along parting and cleavage planes. It cannot be ruled out that at least some of the podiform aggregates of fine-grained muscovite may be of secondary origin.

\section{QUARTZ}

Quartz, usually grey, smoky and milky, rarely colourless and rose, is present in all the pegmatitic zones, although its relative 

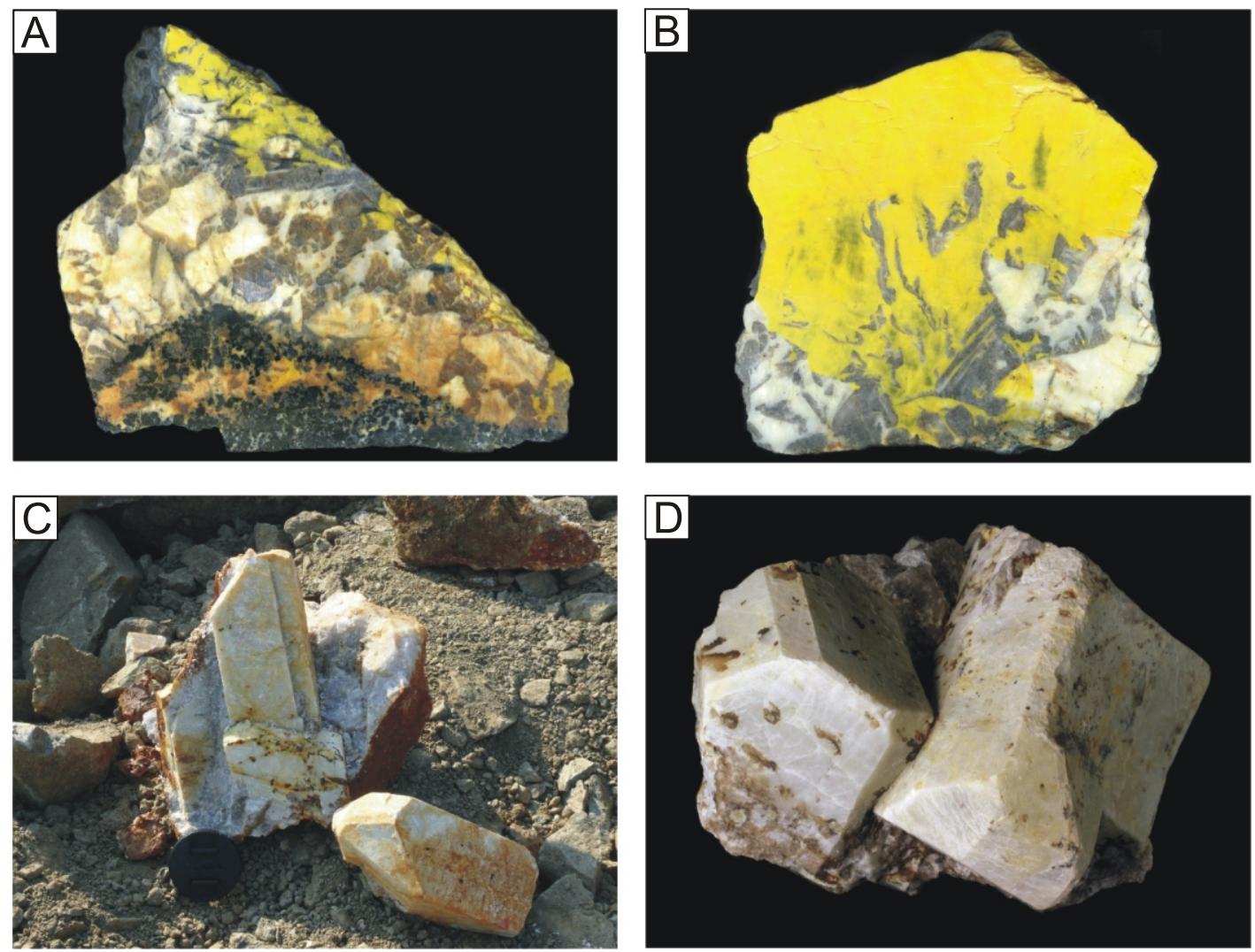

Fig. 7. Feldspars

A - a slice of pegmatite contacting with amphibolite after reaction with cobaltinitrite that stains K-feldspar yellow (modified method of Bailey and Stevens, 1960), close to the contact the pegmatite contains only plagioclase, K-feldspar appears at some distance from the contact; B - a slice of the pegmatite at the transition between the graphic outer intermediate zone and the blocky K-feldspar with euhedral terminations, apart from microcline the graphic zone contains quartz-plagioclase intergrowths; $\mathbf{C}$ - columnar crystals of microcline, the lens cover is $5 \mathrm{~cm}$ across; D - typical crystals of microcline (up to $8 \mathrm{~cm}$ ) with quartz-intergrown cores
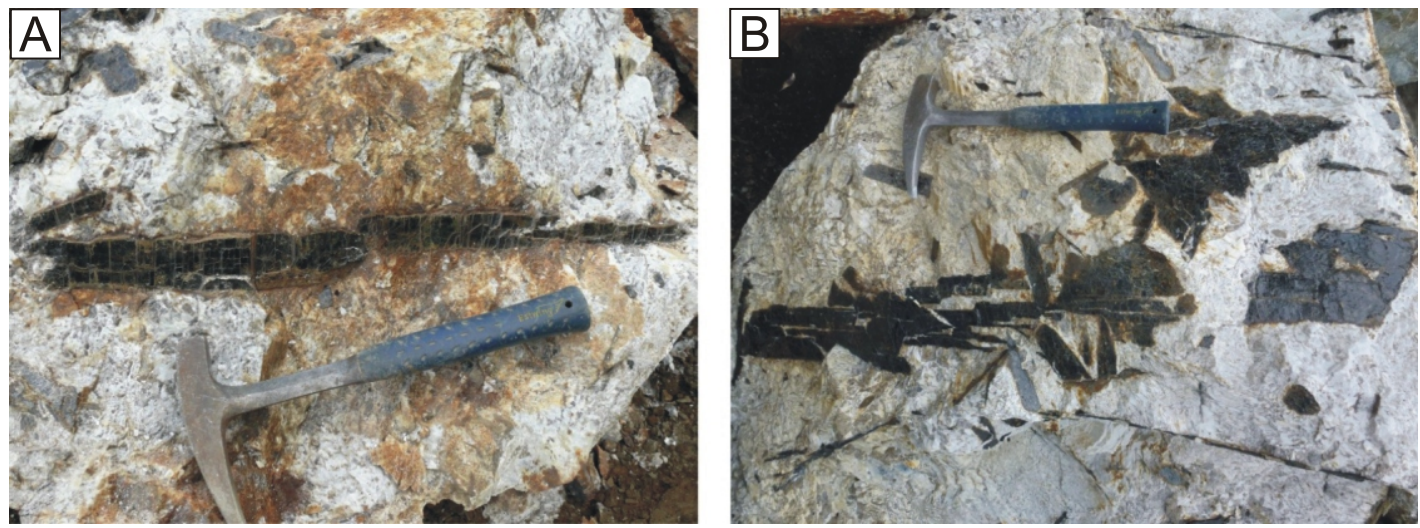

Fig. 8. Biotite laths from the outer intermediate zone

The hammer is $33 \mathrm{~cm}$ long 



Fig. 9. Muscovite

A - randomly-oriented aggregates, the lens cover is $5 \mathrm{~cm}$ across; $\mathbf{B}$ - muscovite-quartz symplectites $(15 \times 10 \mathrm{~cm})$; $\mathbf{C}$ - radial aggregate in microcline $(10 \times 10 \mathrm{~cm})$; $\mathbf{D}$ - fragment of a larger book-like aggregate $(10 \times 10 \mathrm{~cm})$

abundance and habit varies. Irregular anhedral grains are typical of the granite-textured border zone. Interstitial quartz in the spaces between earlier crystallised phases is very common. However, the most prominent textural variety is cuneiform quartz graphically intergrown with feldspars of the outer intermediate zone (Figs. 7B, D and 10A-C). The thickness of the quartz rods increases towards the centre of the dikes and also from the centre towards the margins of individual feldspar crystals, in places exceeding $2 \mathrm{~cm}$. Massive pegmatitic cores represent the latest generation of primary quartz (Fig. 10D). The quartz core usually envelops well-formed crystals of K-feldspar, micas, garnet, beryl and tourmaline that either project from the adjacent intermediate zone or are completely submerged in quartz. However, in some parts of the intermediate zone, quartz turns at least partly euhedral against K-feldspar and shows well-developed locally stepped prismatic and rhombohedral faces. Quartz fracture fillings can be rooted in the quartz cores.

\section{GARNET}

The almandine-spessartine variety of garnet (Nejbert et al., 2010), with colours ranging from dark brown through various shades of red to yellowish-orange, is common in both the intermediate zones and the quartz core (Fig. 11). Large euhedral crystals $(<5 \mathrm{~cm})$ form combinations of rhombic dodecahedra and trapezoidal icositetrahedra, in places grouped in string-like aggregates (Fig. 11). Skeletal garnet intergrown with quartz, more rarely with $\mathrm{K}$-feldspar and muscovite, occurs in the outer intermediate zone. The intergrowths form oval pods, some over $10 \mathrm{~cm}$ long. Similar garnet-quartz intergrowths constitute the cores of larger crystals with quartz-free euhedral margins.
TOURMALINE

Tourmaline of the schorl-dravite series (Pieczka et al., 2010b) forms euhedral prismatic crystals terminated with trigonal pyramids or/and a pedion face (Fig. 12). It occurs from the outer intermediate zone up to the quartz core and its abundance varies inversely with that of biotite. Spectacular giant crystals up to $70 \mathrm{~cm}$ long and $7 \mathrm{~cm}$ across were found in vein Jul $4+5$, straddling the boundary between the two intermediate zones. Common funnel-shaped aggregates spread out towards the dike centres. Tourmaline-quartz symplectites occur as up to $20 \mathrm{~cm}$ large oval pods in the outer intermediate zone. Individual crystals are locally broken with fragments displaced and the fractures sealed by quartz. In thin section tourmaline crystals reveal an internal texture that consists of a core with blue to colourless pleochroism and a rim with pleochroic colours ranging from olive-green through brown to colourless. A late generation of finer-grained tourmaline forms $2-3 \mathrm{~cm}$ long thin and often flattened prisms which occur along the cleavage and parting planes of feldspars.

\section{BERYL AND OTHER Be MINERALS}

Green, pale yellow, rarely white or slightly bluish beryl (Fig. 13) appears from the outer intermediate zone up to the quartz core. It is particularly abundant in muscovite-rich portions of the pegmatites. Beryl forms hexagonal prisms terminated by hexagonal pyramids or pinacoids, up to $15 \mathrm{~cm}$ long and several centimetres wide. Exceptionally well-developed crystals occurred in the quartz cores of veins Jul 4 and Jul5. Characteristic icicle- and pear-shaped crystals thickening towards the pegma- 

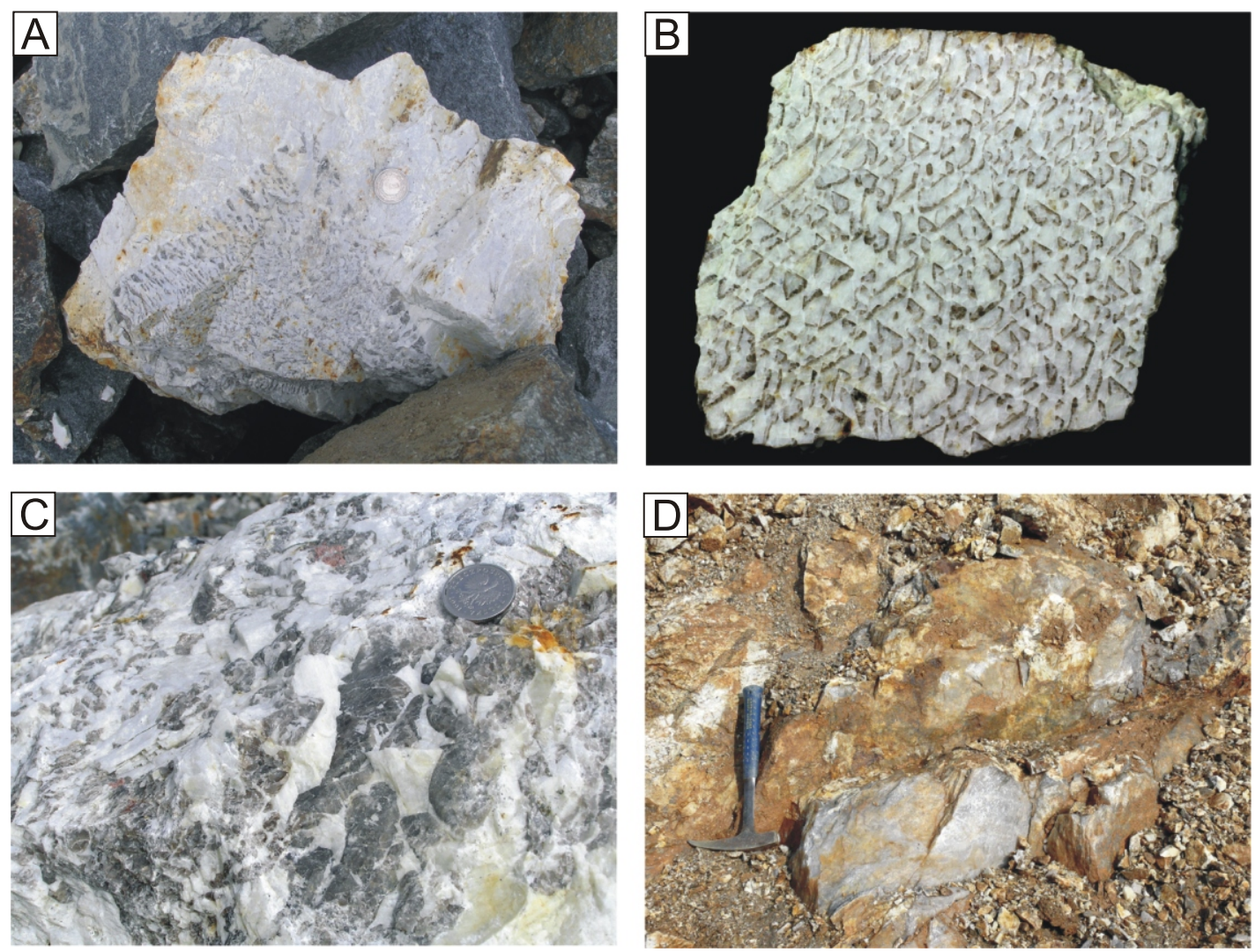

Fig. 10. Quartz

A - quartz-feldspars intergrowths in the core of a large feldspar crystal mantled by quartz-free perthite, the coin is $2 \mathrm{~cm}$ large; $\mathbf{B}$ - typical cuneiform quartz rods intergrown with feldspars from the outer intermediate zone, the polished surface is about $18 \mathrm{~cm}$ long; $\mathbf{C}$ - coarse quartz rods in graphic intergrowths, the coin is $2 \mathrm{~cm}$ across; D - quartz core in the Julianna Jul5 vein in plan view, the hammer is $33 \mathrm{~cm}$ long
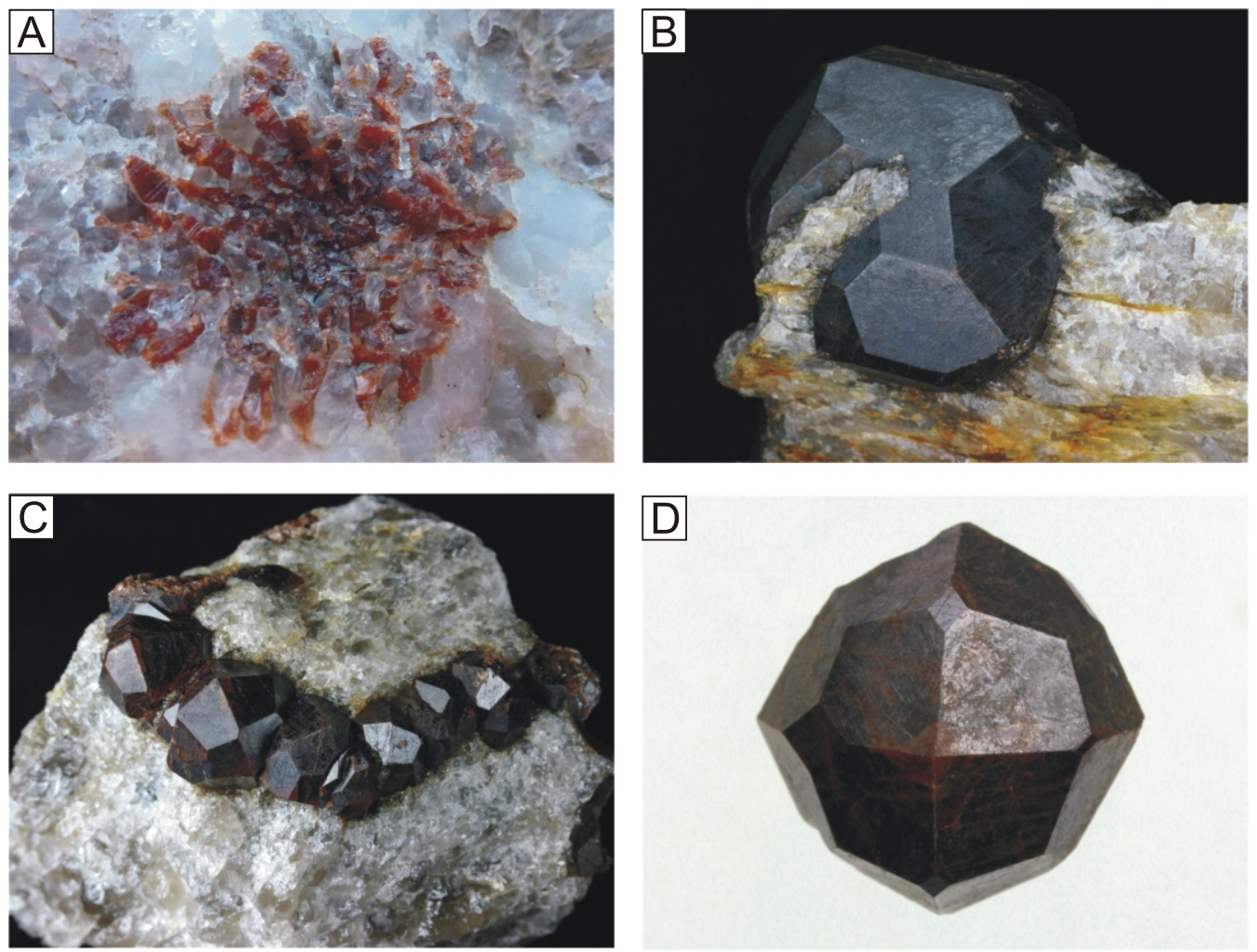

Fig. 11. Garnet

A - garnet-quartz symplectites $(3 \mathrm{~cm})$; B - crystal with the form of a rhombic dodecahedron modified by subordinate trapezoidal icositetrahedron faces $(4 \mathrm{~cm}) ; \mathbf{C}$ - string-like aggregate of crystals up to $1 \mathrm{~cm}$ long in quartz; D - crystal with the form of a rhombic dodecahedron combined with trapezoidal icositetrahedron $(1.5 \mathrm{~cm})$ 

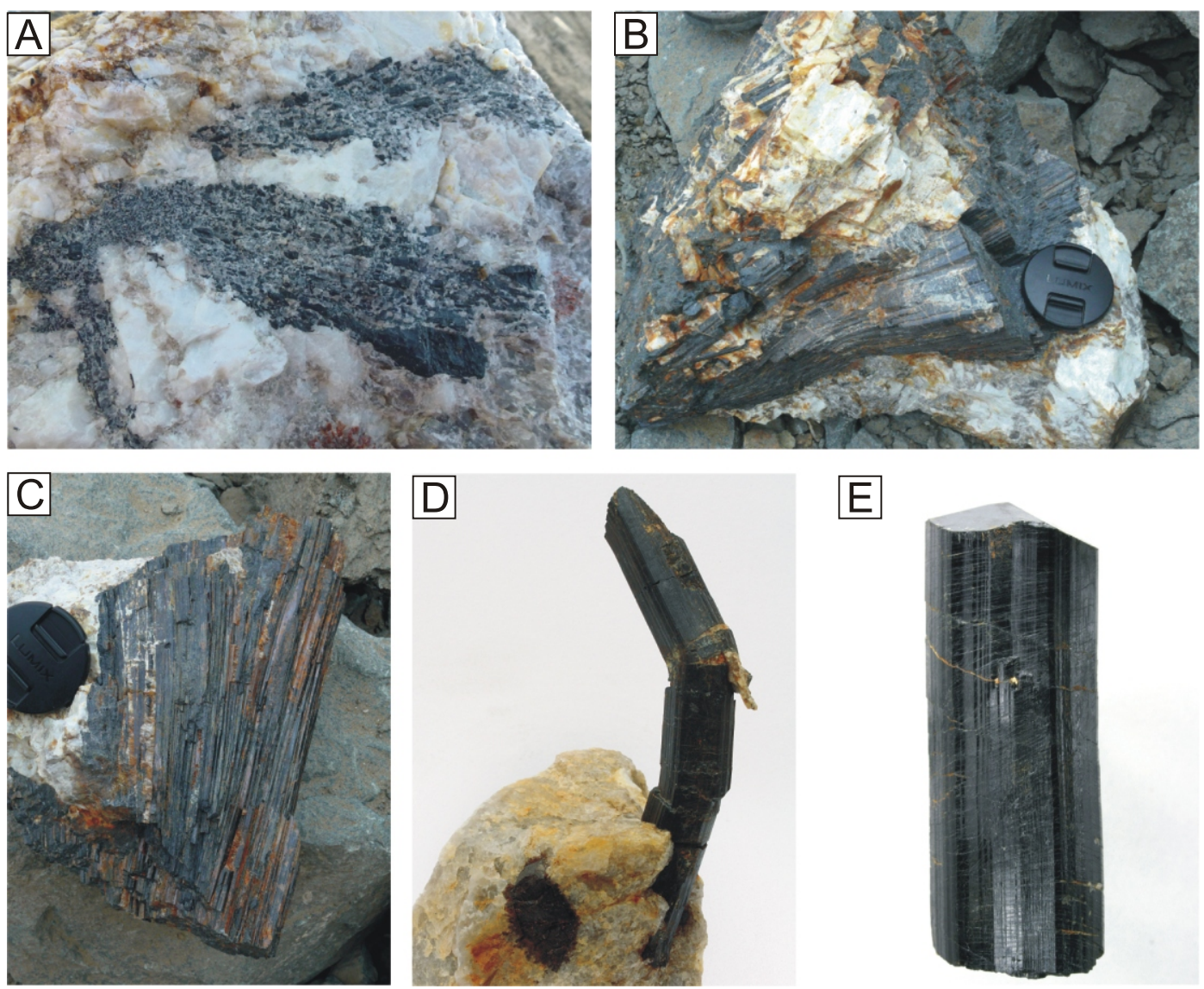

Fig. 12. Tourmaline

A - tourmaline-quartz symplectites (17 cm long); B, C - funnel-shaped aggregates of prismatic crystals, the lens cover is $5 \mathrm{~cm}$ large; $\mathbf{D}$ - fragments broken crystal are displaced and re-sealed with quartz $(7 \mathrm{~cm})$; E - ideal prismatic crystal $(8 \mathrm{~cm})$

titic cores are common. Some beryl crystals contain inclusions of bavenite and phenakite (Łodziński et al., 2010).

\section{COLUMBITE AND OTHER ACCESSORY MINERALS}

Columbite-group minerals predominate over ( $\mathrm{Y}, \mathrm{REE}, \mathrm{Nb}$ $\mathrm{Ta}, \mathrm{Ti})$-rich oxide minerals and include columbite-(Fe), columbite-(Mn) and tantalite-(Fe) (Pieczka et al., 2010a). They are usually associated with beryl and occur as black platy crystals, up to $7 \mathrm{~cm}$ long and $1 \mathrm{~cm}$ wide (Fig. 14) in the intermediate zones and in the quartz core and as thin needles in more differentiated veins (e.g., vein Jul4+5). Zircon, xenotime-(Y), monazite-(Ce), cheralite, samarskite- and euxenite-group minerals (Fig. 15) along with allanite(-Ce), (Nb,Ta)-enriched cassiterite, titanite and ilmenite are relatively common, the other accessory minerals being rare.

\section{LITHIUM- AND CAESIUM-RICH MINERALS}

Li-rich minerals are represented mainly by spodumene, lepidolite, and tourmalines of the elbaite-olenite-rossmanite series along with rare lithiophilite and probably also liberite and eucryptite (Pieczka et al., 2012). A very high degree of Mn-Fe fractionation is also reflected by the composition of garnet close to the spessartine end-member (Nejbert et al., 2010) and the occurrence of columbite-(Mn) and tantalite-(Mn). Cs-rich beryl reaches a composition corresponding to pezzottaite. The whole assemblage is closely associated with primary albite and may represent a distinct late constituent of the zoning sequence described above.

Pollucite occurs together with Li-rich micas, quartz, zeolites and clay minerals in up to $30 \mathrm{~cm}$ large pods within the graphic-intermediate zone. At the present stage of study it is not possible to state whether the pollucite-bearing pods are primary or secondary.

\section{FINAL REMARKS}

Published data on the textural and mineralogical characteristics of the pegmatite occurrences that were mined in historical times in the foreland domain of the GSB unit (Lis and Sylwestrzak, 1986 and references therein) as well as studies of historical samples stored in mineralogical museums suggest that the great majority of these bodies represent a single and relatively uniform pegmatite population. Minor differences seem to be a result of various degrees of geochemical and textural differentiation of individual pegmatites. The newly discovered low to moderately evolved pegmatites from the Piława Górna Quarry are in all respects representative of that population. At the same time the large scale of the Julianna pegmatitic system shows that the potential for similarly evolved pegmatites in GSB has been underestimated (e.g., Mikuszewski et al., 1976).

The Julianna veins were emplaced during a single event in a zone of tectonized amphibolite. Blocks of the country rock behaved in a rigid manner at the time of intrusion. The overall geometry of the Julianna system and relations to the host rock fab- 

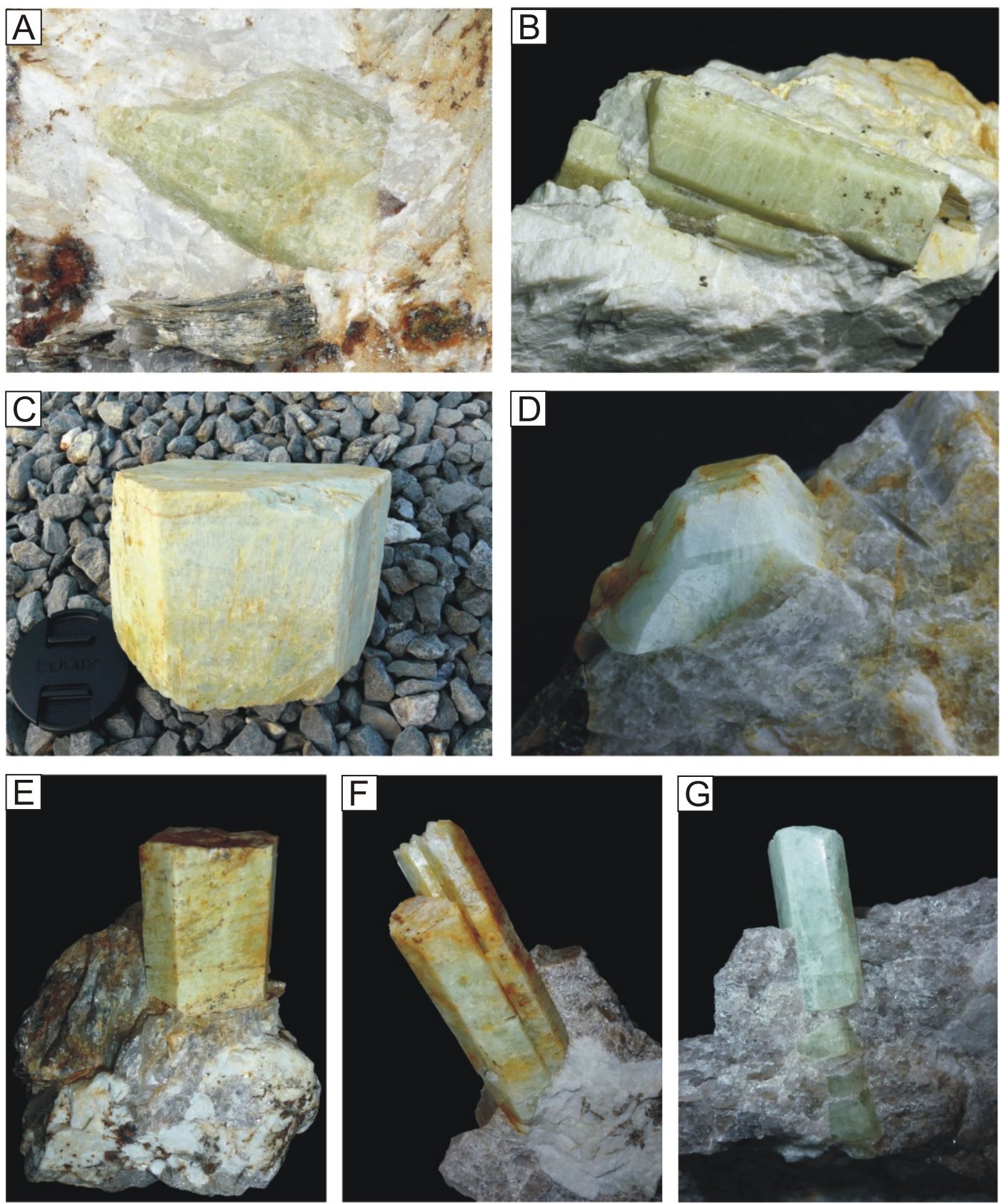

Fig. 13. Beryl

A - pear-shaped crystal $(8 \mathrm{~cm})$; B - prismatic crystals $(6 \mathrm{~cm})$; $\mathbf{C}$ - fragment of a beryl prism terminated by a basal pinacoid $(10 \times 12 \mathrm{~cm})$; $\mathbf{D}$ - short prismatic crystal terminated by deformed pyramid $(4 \mathrm{~cm})$; $\mathbf{E}$ - short prism terminated by basal pinacoid $(7 \mathrm{~cm}$ long); $\mathbf{F}$ - prismatic crystals terminated by multiple pyramids $(10 \mathrm{~cm}$ long); $\mathbf{G}$ - prismatic crystal terminated by a combination of pyramid and pinacoid $(5 \mathrm{~cm})$

ric suggest that the intrusion postdated regional retrograde metamorphism under amphibolite facies conditions and brittle deformation and took place through passive filling of tectonic fractures. The NNE-SSW orientation of the pegmatitic veins conforms to the system of fractures superimposed on larger NW-SE oriented fault planes in the foreland GSB domain (Żelaźniewicz, 1985; Cymerman et al., 1988; Cymerman, 1989). Large veins show a well-developed classical zoning pattern with unidirectional and skeletal solidification textures including comb-like feldspars, biotite and tourmaline, quartz-feldspar graphic intergrowths as well as quartz-muscovite, quartz-garnet and quartz-tourmaline symplectites. Such fea- tures result from substantial undercooling and rapid crystallisation of a pegmatitic melt intruding into cooler country rocks (e.g., London, 2009 and references therein). These observations are in accordance with the model proposed by Żelaźniewicz $(1987,1990)$, in which the pegmatites represent syn-exhumation dikes that sealed sub-vertical tension-related fractures.

The Julianna system represents the rare-element (REL) class pegmatites (see Černý and Ercit, 2005) and exhibits high variability in degree of fractionation and mineralogy. The beryl-columbite subtype prevails although among the most fractionated veins albite-spodumene and perhaps also complex 

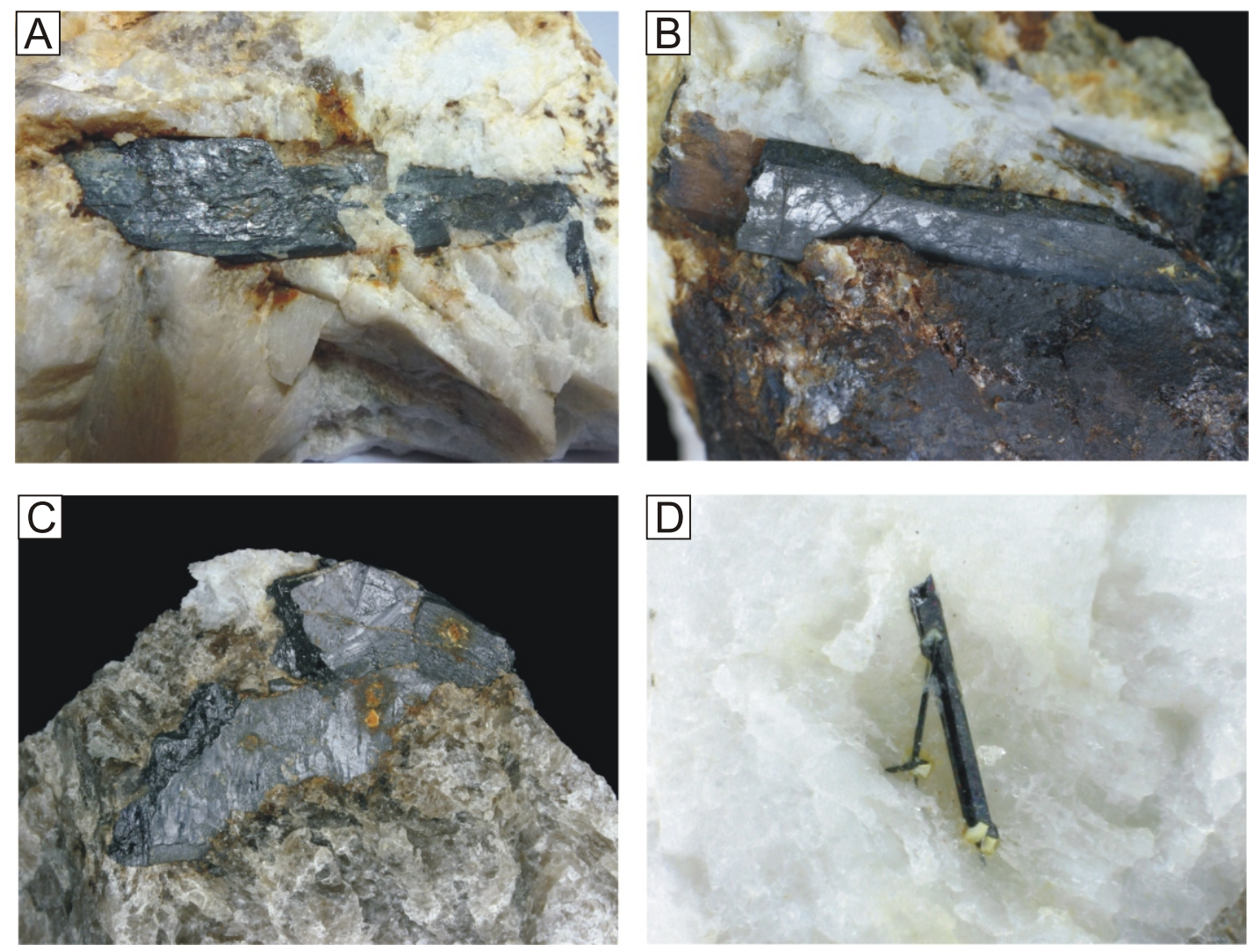

Fig. 14. Columbite

A - the largest known columbite crystal from Piława $(8 \mathrm{~cm}) ; \mathbf{B}-2.2 \mathrm{~cm}$ long prismatic crystal; $\mathbf{C}-3 \mathrm{~cm}$ fragment of a tabular crystal; D $-4 \mathrm{~mm}$ long prismatic crystals overgrown by isometric pale green cheralite

REL types could be distinguished. The current petrogenetic classification of granitic pegmatites distinguishes between two distinct LCT (enriched in Li, Cs and Ta) and NYF (enriched in $\mathrm{Nb}, \mathrm{Y}$ and $\mathrm{F}$ ) families and pegmatites with a hybrid NYF + LCT geochemical signature (Černý, 1991; Černý and Ercit, 2005). The majority of the Julianna veins, which display a low to moderate degree of fractionation, contain typical NYF-signature accessory minerals, such as allanite-(Ce), columbite-, euxeniteand samarskite group minerals, fergusonite- $(\mathrm{Y})$ and gadolinite- $(Y)$. However, with increasing fractionation, the mineral assemblage of the most evolved pegmatites displays the LCT signature as shown by the presence of spodumene, lepidolite, pollucite and other $\mathrm{Li}$ - and Cs-rich minerals. Therefore the entire pegmatitic system is assigned to the mixed NYF + LCT family. Genetic scenarios proposed to explain the mode of origin of hybrid NYF + LCT pegmatites include partial melting of an only partially depleted crustal source, anatexis of mixed depleted and undepleted lithologies as well as various possibilities of external contamination (Černý, 1991; Černý and Ercit, 2005; Martin and De Vito, 2005; Novák et al., 2012).

The data available do not allow the drawing of a coherent model for the origin of the Julianna pegmatitic system. Current concepts of the geological evolution of the GSB relate the origin of minor granitic and pegmatitic bodies to anatectic melting of the source rocks that comprise both supracrustal and mantle-related lithologies (e.g., Grocholski, 1967; Morawski, 1973; Kryza, 1981; Gunia, 1985; Żelaźniewicz, 1987, 1990; Kröner and Hegner, 1998; Kryza and Pin, 2002). Such protoliths have the potential to generate melts with LCT, NYF as well as hybrid LCT + NYF geochemical signatures. The anatectic GSB granitoids and pegmatites solidified at about the same time at 370-380 Ma (Breemen et al., 1988; Timmermann et al., 2000). However, there is no compelling evidence that they are consanguineous and it remains unknown whether the pegmatitic melts were derived directly from small amounts of partial melts or were subjected to differentiation processes in a pluton-sized reservoir of anatectic magma.

Another important issue to be addressed before a petrogenetic scheme for the Julianna pegmatites can be proposed is the possibility of external contamination of the pristine pegmatite-forming melt. In situ contamination from the mantle-related host amphibolite (Kryza and Pin, 2002; Innicki et al., 2012) could add NYF characteristics to the solidifying melt. However, abundant unidirectional and skeletal textures indicate disequilibrium crystallisation at high undercooling values and the meter-scale thickness of individual dikes implies rapid solidification of the pegmatites. Thus interaction of the melt with the host rocks was strongly limited in time. Also the sharp amphibolite-pegmatite contacts, mostly angular shape of amphibolite xenoliths included into the pegmatites and the poorly developed exocontact, only a few centimetres thick, suggest that the effect of in situ contamination was of minor importance. On the other hand, the possibility of melt contamination prior its emplacement remains an open question. 



Fig. 15. Accessory minerals

A - elongated zircon (1 cm); B - isometric zircon epitaxy on yellow xenotime $(1 \mathrm{~cm})$; $\mathbf{C}$ - xenotime-zircon intergrowths $(0.5 \mathrm{~cm})$; $\mathbf{D}$ - tabular monazite $(1 \mathrm{~cm})$; $\mathbf{E}$ - isometric cheralite (up to $1 \mathrm{~mm}$ ) on columbite; $\mathbf{F}$ - crystals of samarskite-euxenite group minerals $(<1 \mathrm{~cm})$

Systematic mineralogical and geochemical studies of the pegmatites from the Piława Górna Quarry are currently in progress. Although preliminary, the results presented here provide compelling evidence for the Julianna pegmatitic system as a unique mineralogical occurrence in the Bohemian Massif

Acknowledgements. The authors would like to express their deepest gratitude to the authorities of the Dolnoślaskie Surowce Skalne mining company for their exceptional and unprecedented help during field work. We are particularly very thankful to J. Łuczak, the recently deceased president of the
DSS Company, for his great understanding, personal involvement and interest in our research. The pegmatitic system described in the paper is named after his younger daughter Julianna. We also would like to thank M. Roman, the current DSS president, and $\mathrm{M}$. Then as well as all members of the company's and mine's managements for continuing this exemplary cooperation. The authors thank R. Macdonald for improving the English version of the text and the reviewers: D. London, M. Novák and J. Janeczek for their helpful discussion on the manuscript. The study was financed by the Ministry of Science and Higher Education grant NN307 241737. 


\section{REFERENCES}

Aftalion M., Bowes D.R. (2002) U-Pb zircon isotopic evidence for Mid-Devonian migmatite formation in the Gory Sowie domain of the Bohemian Massif, Sudeten Mountains, SW Poland. Neues Jahrbuch für Mineralogie, Monatshefte, (4): 182-192.

Aleksandrowski P., Kryza R., Mazur S., Żaba J. (1997) Kinematic data on major Variscan strike-slip faults and shear zones in the Polish Sudetes, northeast Bohemian massif. Geological Magazine, 133: 727-739.

Badura J., Zuchiewicz W., Gorecki A., Sroka W., Przybylski B., Zyszkowska M. (2003) Morphotectonic properties of the Sudetic marginal fault, SW Poland. Acta Montana IRSM AS CR, Ser. A, 24: 21-49.

Bailey E.H., Stevens R.E. (1960) Selective staining of K-feldspar and plagioclase on rock slabs and thin sections. American Mineralogist, 45: 1020-1025.

Breemen O. van, Bowes D.R., Aftalion M., Żelaźniewicz A. (1988) Devonian tectonothermal activity in the Sowie Góry gneissic block, Sudetes, southwestern Poland: evidence from $\mathrm{Rb}-\mathrm{Sr}$ and $\mathrm{U}-\mathrm{Pb}$ isotopic studies. Annales Societatis Geologorum Poloniae, 58: 3-10.

Bröcker M., Żelaźniewicz A., Enders M. (1998) Rb-Sr and U-Pb geochronology of migmatic gneisses from the Góry Sowie (West Sudetes, Poland): the importance of Mid-Late Devonian metamorphism. Journal of the Geological Society, 155: 1025-1036.

Brueckner H.K., Blusztajn J., Bakun-Czubarow N. (1996) Trace element and $\mathrm{Sm}-\mathrm{Nd}$ "age" zoning in garnets from peridotites of the Caledonian and Variscan mountains and tectonic implications. Journal of Metamorphic Geology, 14: 61-73.

Černý P., Ercit T.S. (2005) The classification of granitic pegmatites revisited. Canadian Mineralogist, 43: 2005-2026.

Černý P. (1991) Fertile granites of Precambrian rare-element pegmatite fields: is geochemistry controlled by tectonic setting or source lithologies? Precambrian Research, 51: 429-468.

Cymerman Z. (1989) Structural development of the Góry Sowie metamorphic terrain in the vicinity of Piława Górna, the Sudetes (in Polish with English summary). Geologia Sudetica, 23 (2): 107-153.

Cymerman Z., Walczak-Augustyniak M. (1988) Szczegółowa mapa geologiczna Sudetów 1:25 000, arkusz Dzierżoniów. Wydawnictwa Geologiczne, Warszawa.

Dathe E., Finckh L. (1924) Erläuterungen zu Blatt Charlottenbrunn. Geologischen Karte von Preussen und benachbarten deutschen Ländern 1:25 000. Lief. 254 Preussisches Geologisches Landesamt. Berlin.

Dumańska-Słowik M. (2004) Mineralogical and geochemical investigation of micas from the Góry Sowie Mts. pegmatites. Mineralogia Polonica, 35 (2): 27-37.

Fiedler H. (1863) Die Mineralien Schlesiens mit Berücksichtigung der angrenzenden Länder. Breslau.

Gordon S.M., Schneider D.A., Manecki M., Holm D.K. (2005) Exhumation and metamorphism of an ultrahigh-grade terrane: geochronometric investigations of the Sudetes Mountains (Bohemia), Poland and Czech Republic. Journal of the Geological Society, 162: 841-855.

Grocholski W. (1964) On the geology of the vicinity of Kamionkowo in the Sudetes Mountains (in Polish with English summary). Geologia Sudetica, 1: 209-220.

Grocholski W. (1967) Structure of the Sowie Mts (in Polish with English summary). Geologia Sudetica, 3: 181-249.

Gunia T. (1985) Geological position of the Sowie Góry block and its influence on the paleogeography of the Paleozoic of Central Sudetes (in Polish with English summary). Geologia Sudetica, 20: $83-119$

Gunia P. (1997) Petrology of ultrabasic rocks from the Góry Sowie block (in Polish with English summary). Prace GeologicznoMineralogiczne, 65: 1-78.

Hintze C. (1933) Handbuch der Mineralogie, Bd. 1/4. Cruyter and Co., Berlin und Leipzig.
Ilnicki S., Nejbert K., Pieczka A., Szełęg E., Turniak K., Szuszkiewicz A., Łodziński M., Banach M., Michałowski P., Różniak R. (2010) Eclogites from the Piława Górna Quarry (Dolnoślaskie Surowce Skalne S.A.), Góry Sowie Block, SW Poland: a preliminary report. Mineralogia - Special Papers, 37: 81.

IInicki S., Nejbert K., Pieczka A., Szełęg E., Turniak K., Szuszkiewicz A., Łodziński M., Banach M., Michałowski P., Różniak R. (2011) Metamorphic record of retrogressed eclogites from the Piława Górna (Sowie Góry block, SW Poland). Mineralogia - Special Papers, 38: 103-104.

Ilnicki S., Nejbert K., Pieczka A., Szełęg E., Turniak K., Szuszkiewicz A., Łodziński M. (2012) Geochemical and petrological features of eclogites from Piława Górna (Góry Sowie Block, SW Poland). Mineralogia - Special Papers, 40: 78-79.

Kröner A., Hegner E. (1998) Geochemistry, single zircon ages and Sm-Nd systematics of granitoid rocks from the Góry Sowie (Owl Mts.), Polish West Sudetes: evidence for early Palaeozoic arc-related plutonism. Journal of the Geological Society, 155: 711-724.

Kryza R. (1977) Cordierite-bearing pegmatite within serpentinites of the environs of Lubachów (Sowie Góry Mts., Sudetes) (in Polish with English summary). Annales Societatis Geologorum Poloniae, 47 (2): 247-263.

Kryza R. (1981) Migmatization in gneisses of the northern part of the Sowie Góry, Sudetes (in Polish with English summary). Geologia Sudetica, 14: 7-100.

Kryza R., Fanning C.M. (2007) Devonian deep-crustal metamorphism and exhumation in the Variscan Orogen: evidence from SHRIMP zircon ages from HT-HP granulites and migmatites of the Góry Sowie (Polish Sudetes). Geodinamica Acta, 20 (3): 159-175.

Kryza R., Pin C. (2002) Mafic rocks in a deep-crustal segment of the Variscides (the Góry Sowie, SW Poland): evidence for crustal contamination in an extensional setting. International Journal of Earth Sciences, 91: 1017-1029.

Lis J., Sylwestrzak H. (1986) Minerały Dolnego Śląska (in Polish). Wydawnictwa Geologiczne, Warszawa.

Łodziński M. (2007) Mineralogical study of beryls from the Polish and Czech parts of the Sudety Mts (in Polish with English summary). Prace Mineralogiczne, 93: 1-79.

Łodziński M. (2008) Chemical composition of columbite-group minerals from selected pegmatites in the Góry Sowie Mts, Strzelin-Zulova and Hruby Jesenik massifs - preliminary data. Mineralogia - Special Papers, 32: 105-106.

Łodziński M., Pieczka A. (2008) (Nb-Ta)-oxide minerals from pegmatites of the Owiesno-Kietlice area in the Sowie Mts. block, Southwestern Poland. Mineralogia - Special Papers, 32: 108.

Łodziński M., Pieczka A., Szełęg E., Nejbert K., Szuszkiewicz A., Turniak K., Ilnicki S., Banach M., Michałowski P., Różniak R. (2010) Beryllium minerals (beryl, phenakite and bavenite) in pegmatites of the DSS mine at Piława Górna, Góry Sowie Block, SW Poland. Mineralogia - Special Papers, 37: 91-92.

London D. (2009) The origin of primary textures in granitic pegmatites. Canadian Mineralogist, 47: 697-724.

Martin R. F., Vito C. de (2005) The patterns of enrichment in felsic pegmatites ultimately depend on tectonic setting. Canadian Mineralogist, 43: 2027-2048.

Mazur S., Aleksandrowski P., Turniak K., Awdankiewicz M. (2007) Geology, tectonic evolution and Late Palaeozoic magmatism of Sudetes - an overview. AM Monograph, 1: 59-87.

Mikuszewski J., Kanasiewicz J., Jęczmyk M. (1976) Beryllium, tin, lithium, niobium and elements of rare earths in pegmatites and other crystalline rocks of the Góry Sowie (Mts.), the Sudetes. In: The Current Metallogenic Problems of Central Europe (ed. J. Fedak): 290-304. Wydawnictwa Geologiczne, Warszawa.

Morawski T. (1973) The Sowie Góry area and its petrological problems. In: Revue des Problèms Géologiques des Zones 
Profondes de L'écorce Terrestre en Basse Silesie (ed. K Smulikowski): 44-58. Wydawnictwa Geologiczne, Warszawa.

Nejbert K., Pieczka A., Szełęg E., IInicki S., Szuszkiewicz A., Łodziński M., Turniak K., Banach M., Michałowski P., Różniak R. (2010) Textural and chemical varieties of garnets in the pegmatites from Piława Górna quarry (Dolnośląskie Surowce Skalne S.A.), Góry Sowie Block, southwestern Poland. Mineralogia - Special Papers, 37: 96.

Novák M., Škoda R., Gadas P., Krmiček L., Černý P. (2012) Contrasting origins of the mixed (NYF+LCT) signature in granitic pegmatites, with examples from the Moldanubian zone, Czech Republic. Canadian Mineralogist, 50: 1077-1094.

O’Brien P.J., Kröner A., Jaeckel P., Hegner E., Żelaźniewicz A., Kryza R. (1997) Petrological and isotope studies on Palaeozoic high-pressure granulites. Góry Sowie Mts, Polish Sudetes. Journal of Petrology, 38 (4): 433-456.

Pieczka A. (1996) Mineralogical study of Polish tourmalines. Prace Mineralogiczne, 85: 1-79.

Pieczka A., Gołębiowska B., Kraczka J. (1997) Mn-garnets from the Sowie Mts metamorphic pegmatites. Mineralogia Polonica, 28 (2): 81-88.

Pieczka A., Gołębiowska B., Skowroński A. (2003) Ferrisicklerite and other phosphate minerals from the Lutomia pegmatite (SW Poland, Lower Silesia, Góry Sowie Mts). International Symposium on Light Elements in Rock-forming Minerals, Nové Město na Moravě, Czech Republic, Book of abstracts: 63-64.

Pieczka A., Łobos K., Sachanbiński M. (2004) The first occurrence of elbaite in Poland. Mineralogia Polonica, 35 (1): 3-14.

Pieczka A., Szełęg E., Łodziński M., Szuszkiewicz A., Nejbert K., Turniak K., Ilnicki S. (2010a) Nb-Ta minerals in pegmatites in the DSS mine at Piława Górna, Góry Sowie Block, southwestern Poland. Mineralogia - Special Papers, 37: 101.

Pieczka A., Szełęg E., Łodziński M., Szuszkiewicz A., Nejbert K., Turniak K., Ilnicki S. (2010b) Mn-Fe fractionation in tourmalines from pegmatites in the DSS mine at Piława Górna, Góry Sowie Block, southwestern Poland (preliminary data). Mineralogia - Special Papers, 37: 100.

Pieczka A., Szełęg E., Szuszkiewicz A., Łodziński M., Nejbert K., Turniak K., Ilnicki S., Banach M., Michałowski P., Różniak R. (2010c) Lithium pegmatite from the DSS Piława Górna mine, Góry Sowie Block, southwestern Poland. Mineralogia - Special Papers, 37: 99.

Pieczka A., Łodziński M., Szełęg E., Ilnicki S., Nejbert K., Szuszkiewicz A., Turniak K., Banach M., Michałowski P., Różniak R. (2012) The Sowie Mts. pegmatites (Lower Silesia, SW Poland): a current knowledge. Acta MineralogicaPetrographica, 7: 105-106.

Polański A. (1955) On the metamorphism of crystalline formations of the Sowie Mts (Middle Sudeten) (in Polish with English summary). Archiwum Mineralogiczne, 18: 211-284.
Römer F. (1864) Über die Auffindung des Columbit. Jahresbericht der schlesischen Gesellschaft für vaterländische Kultur, 41.

Roth J. (1867) Erläuterungen zu der geognostischen Karte von Niederschlesichen Gebirge und den umliegenden Gegenden. Berlin.

Sachanbiński M. (1971) Geochemia berylu w skałach krystalicznych Gór Sowich. In: Pierwiastki rzadkie i metalurgia chemiczna I. Prace Naukowe Instytutu Chemii Nieorganicznej i Metalurgii Pierwiastków Rzadkich Politechniki Wrocławskiej, 3: 177-187.

Sachanbiński M. (1972) Minerały Gór Sowich. Biuletyn Informacyjny Polskiego Towarzystwa Przyjaciół Nauk o Ziemi: $35-42$.

Sachanbiński M. (1973) Występowanie minerałów berylowych na Dolnym Śląsku. Biuletyn Instytutu Geologicznego, 264: 249-260.

Smulikowski K. (1952) The old crystalline formations of the Sudeten Mountains (in Polish with English summary). Rocznik Polskiego Towarzystwa Geologicznego, 21 (1): 67-124.

Szełęg E., Gałuskina I. (2010) Mineralogy of Lower Silesia, Poland. Acta Mineralogica-Petrographica. Field Guide Series, 17: 15.

Szełęg E., Szuszkiewicz A., Pieczka A., Nejbert K., Turniak K., Łodziński M., Ilnicki S., Banach M., Michałowski P., Różniak R. (2010) Geology of the Julianna pegmatite vein system from the Piława Górna quarry (Dolnośląskie Surowce Skalne S.A.), Sowie Mts Block, SW Poland. Mineralogia - Special Papers, 37: 111.

Timmermann H., Parrish R.R., Noble S.R., Kryza R. (2000) New $\mathrm{U}-\mathrm{Pb}$ monazite and zircon data from the Sudetes Mountains in SW Poland; evidence for a single-cycle Variscan Orogeny. Journal of the Geological Society, 157 (2): 265-268.

Traube H. (1888) Die Minerale Schlesiens. Breslau.

Websky M. (1868) Über Sarkopsid und Kochelit, zwei neue Minerale aus Schlesien. Zeitschrift der Deutschen Geologischen Gesellschaft, 20: 245-257.

Zawidzki P. (1971) Trace elements in micas from Sowie Góry gneisses (in Polish with English summary). Archiwum Mineralogiczne, 29 (1-2): 119-157.

Żelaźniewicz A. (1985) Granulitic inliers amidst a gneissic-migmatitic complex of the Owl Mts, Sudetes. Acta Geologica Polonica, 35: 157-171.

Żelaźniewicz A. (1987) Tectonic and metamorphic evolution of the Góry Sowie, Sudetes Mts, SW Poland (in Polish with English summary). Annales Societatis Geologorum Poloniae, 57: 203-348.

Żelaźniewicz A. (1990) Deformation and metamorphism in the Góry Sowie gneiss complex, Sudetes, SW Poland. Neues Jahrbuch für Geologie und Paläontologie Abhandlungen, 179: 129-157.

Żelaźniewicz A. (1995) Fore-Sudetic part of the Góry Sowie Block, SW Poland (in Polish with English summary). Annales Societatis Geologorum Poloniae, 66: 85-109. 